
\title{
B Reserach S Surare \\ The Prevalence of Digestive Tract Defects in China: A Population-Based Study
}

\section{Fangfang Song ( $\square$ sffkelly@126.com )}

Shanghai Jiaotong University School of Medicine Xinhua Hospital

Jie Chen

Shanghai Jiaotong University School of Medicine Xinhua Hospital

Wei Cai

Shanghai Jiaotong University School of Medicine Xinhua Hospital

\section{Research article}

Keywords: Digestive tract defects, Incidence, China, Population-based study

Posted Date: December 23rd, 2020

DOl: https://doi.org/10.21203/rs.3.rs-132228/v1

License: (c) (i) This work is licensed under a Creative Commons Attribution 4.0 International License. Read Full License 


\section{Abstract}

Objectives: The prevalence of congenital digestive tract defects among Chinese people is rarely reported. The aim of this study was to investigate the incidence of digestive tract defects in mainland China and reported the clinical outcomes of these cases.

Methods: This research describes a local population-based study of registered births in Jiaxing, China from January 2015 to December 2019. Prevalence estimates (per 10,000 births) of digestive tract malformations were calculated. We used the $\chi^{2}$ test to compare the differences between categorical variables.

Results: In this study a total of 76 cases of digestive tract malformations were included. We calculated the following incidence rates per 10,000 births: 1.65 for esophageal atresia; 1.24 for congenital defects of gastric musculature; 2.33 for hypertrophic pyloric stenosis; 3.72 for duodenal and intestinal atresia; 2.25 for congenital malrotation of intestine; 1.45 for Hirschsprung's disease; 4.75 for anal atresia/stricture; and 1.40 for biliary atresia. There were 31 cases $(40.8 \%)$ of low birth weight $(<2500 \mathrm{~g}), 28$ cases $(36.8 \%)$ were premature births ( $<37$ weeks), and 25 cases $(32.9 \%)$ had concomitant congenital heart disease.

Conclusions: This study estimated the incidence of digestive tract malformations, and the findings may provide a foundation for future epidemiologic studies of these congenital diseases in mainland China. In addition, we found that roughly one third of our subjects with digestive tract defects also had concomitant congenital heart disease, suggesting a link between the two which may warrant further investigation. Moreover, our data will also be helpful in determining the resources needed for basic and public health research into digestive tract malformation in China.

\section{Background}

Congenital malformation of the digestive tract is a phenotypically and etiologically diverse condition, comprising a group of common congenital malformations caused by various factors during fetal development $[1,2]$. These factors include a range of chromosomal anomalies, genetic predisposition, geographic or ethnic population effects, and other unknown factors [3-6].

There have been many population-based epidemiological studies on digestive tract malformations in Europe and America, which showed that the incidence of digestive tract malformation varies by race and country [7-15]. These studies conducted a number of large-sample, population-based retrospective analyses on the epidemic status of neonatal digestive tract malformation, and reported on the incidence, clinical features, and complications of neonatal digestive tract malformation in different regions and time periods. National estimates of the prevalence of birth defects represent an important foundation for our understanding of the public health burden resulting from these conditions. This information can comprehensively reflect the average level of major risk factors for neonatal digestive tract malformation in a region, also provide an important reference for the early detection, treatment, and prognosis of neonatal digestive tract malformation in the future $[6,16,17]$. 
China is a vast territory with a large and fluid population base, so it is difficult to compile very large sample reports focusing on digestive tract malformations in mainland China. At present, the estimated incidence of digestive tract malformations in mainland China is based on epidemiological studies published abroad, and most mainland Chinese studies have focused on clinical experience and genetics [18-24]. Therefore, we seek to objectively and comprehensively ascertain the prevalence of congenital digestive tract malformation in one region and countrywide.

The purpose of this study was to investigate the incidence of digestive tract defects in the population of Jiaxing, using a large database of residents born between 2015 and 2019, in order to gain a clearer picture of the epidemiology of gastrointestinal defects in mainland China.

\section{Methods}

\section{Data presentation}

The data used in the study were obtained from the birth defect surveillance network of Jiaxing Maternal and Child Health Care Hospital. This is the main maternal and child healthcare center in Jiaxing, and is responsible for the annual registration of births and birth defects in Jiaxing region. The total permanent population of Jiaxing region is approximately 5 million, and the average annual birth rate is between 30,000 and 35,000 [25]. All registries in this study comprised local registered populations, including all births from mothers residing in Jiaxing City from January 2015 to December 2019. Data used in this study also included birth defect registers, with abnormalities diagnosed prenatally, at birth, or within seven days of delivery. The total number of births covered by the five-year period in this study was 74,294 . Following exclusion of 25,920 records from the migrant population, a total of 48,374 local subjects were analyzed in the study, and 1,656 of these had birth defects. Birth defects eligible for inclusion in the study were classified as "the presence of one or more birth defects during the data collection period".

\section{Focus: digestive tract defects}

All digestive tract defect cases were coded using the WHO International Classification of Disease (ICD) version 10. The digestive tract defects included in this study were esophageal atresia, congenital defects of gastric musculature, hypertrophic pyloric stenosis, duodenal and intestinal atresia, congenital malrotation of intestine, Hirschsprung's disease, anal atresia/stricture, and biliary atresia, all registered within seven days of birth. As some digestive tract defects such as hypertrophic pyloric stenosis, Hirschsprung's disease, and biliary atresia are not always detected in the neonatal period, these cases were collected from medical records. In order to confirm the final diagnosis, all surviving children's parents were interviewed by telephone.

\section{Data analysis}


The study included 76 cases with digestive tract defects. The total prevalence of digestive tract defects in each year was calculated as the number of cases per 10,000 total births or per 1,000 defects, and $95 \%$ confidence intervals (Cls) were derived from the binomial distribution. If the sample size was less than the number that could be used to calculate the $95 \% \mathrm{Cl}$, then the figure was expressed per 10,000 births. All statistical analyses were performed using $\mathrm{R}$ version 3.6.0.

\section{Results}

\section{Overall prevalence of birth defects in Jiaxing, 2015-2019}

Table 1 shows the overall prevalence of birth defects, including non-digestive in Jiaxing residents during the five-year period (2015-2019) covered by this study. Of the 48,374 participants, 1,656 cases had one or more congenital defects. The overall incidence of birth defects was $3.42 \%$. Among the total subjects with birth defects there were 910 males (55.0\%) and 737 females (44.5\%), and 9 cases $(0.5 \%)$ were indeterminate.

\section{Total prevalence of digestive tract defects in Jiaxing, 2015-2019}

There was a total of 76 cases with digestive tract defects. The prevalence estimates per 10,000 births were as follows: 1.65 for esophageal atresia (8 cases); 1.24 for congenital defects of gastric musculature (6 cases); 2.33 for hypertrophic pyloric stenosis ( 2 cases) in 2019; 3.72 for duodenal and intestinal atresia (18 cases); 2.25 for congenital malrotation of intestine ( 9 cases) in 2016-2019; 1.45 for Hirschsprung's disease ( 6 cases); 4.75 for anal atresia/stricture ( 23 cases); and 1.40 for biliary atresia ( 4 cases) in 2017-2019 (Table 2).

\section{Gender occurrence and outcome of digestive tract defects in Jiaxing, 2015-2019}

Of the 76 cases with digestive tract malformations, 49 were male $(60.5 \%)$ and 29 were female $(38.2 \%)$, giving a male-to-female ratio of $1.58: 1$, and 1 case $(1.3 \%)$ was indeterminable. The rate of death within 0-6 days was $9.2 \%$ (7 cases), while 22.4\% (17 cases) were stillbirths, and 68.4\% (52 cases) were live births (Table 3).

\section{Birth weight and gestational age with digestive tract defects in Jiaxing, 2015-2019}

Table 4 showed the mean birth weight of the cases with digestive tract defects was $2589.01 \pm 877.4(\mathrm{~g})$. Eleven cases $(14.5 \%)$ had a very low birth weight $(<1500 \mathrm{~g}), 20$ cases $(26.3 \%)$ had a low birth weight (1500 2499g), and $40.8 \%$ of cases had a low birth weight in this study. Moreover, the mean gestational age of the digestive tract defect cases was $36.0 \pm 4.0$ weeks, which is below normal gestation $(\geq 37$ weeks). There were 28 cases (36.8\%) born at less than 37 weeks, and 48 cases (63.2\%) were born at fullterm. Among the total cases in our study, 25 (32.9\%) had concomitant congenital heart disease.

\section{Discussion}


At the present time, the incidence of congenital digestive tract defects among mainland Chinese people is rarely reported. Our study presents up-to-date figures for prevalence of congenital digestive tract defects in the population of Jiaxing City, China. In order to evaluate the incidence of digestive tract malformation in this region most accurately, our study is mainly based on analysis of the local registered population in a specific region. This study describes in a standardized way, a large number of cases with digestive tract malformation by a total prevalence per 10,000 births.

Our results showed that the overall incidence of birth defects was $3.42 \%$. A study by Wang [26] reported that the incidence in Jiaxing was $2.1 \%$ between 2006 and 2010. The increase in the prevalence may be due to different registration methods during our study period.

Compared with other regions and countries, the incidence of congenital digestive tract defects in Jiaxing City of this study was different (Table 5). According to previous reports, the rates of esophageal atresia in Europe (2.23-2.57 per 10,000 births from 1987-2006; 2.56 per 10,000 births from 1980-1988) [27, 28] and Hawaii (2.2 per 10,000 births from 1989-2000) [29] were higher than in Jiaxing. The prevalence of hypertrophic pyloric stenosis in Taiwan Region (3.9 per 10,000 births from 1997-2007) [17] and in Sweden (8.5 per 10,000 births from 1987-1996) [30] was higher than in the present study. However, the data in our study included hypertrophic pyloric stenosis in only one year; this warrants further investigation in the future. A previous study showed that the incidence of duodenal atresia in England was $0.7-1.8$ per 10,000 births [31]. Studies from Europe reported the overall incidence of Hirschsprung's disease in Europe was 1.03-1.05 per 10,000 births [5] and in England was 1.33-1.98 per 10,000 births [32]; these findings are similar to the prevalence in our study (1.45 per 10,000 births). The prevalence of anorectal atresia/stricture in a worldwide survey in 2006 (2.0-6.67 per 10.000 births) [33] and in Europe (4.05 per 10,000 births) [34] was also similar to our study. Previous studies reported that the incidence of biliary atresia in Taiwan Region was $0.89-1.90$ per 10,000 births [35], in Japan was 0.96 per 10,000 births [36], and in Korea was $0.93-1.19$ per 10,000 births [37], while in New York it was $0.76-0.93$ per 10,000 births [38] and in overall USA it was $0.65-0.85$ per 10,000 births [39]. The incidence in Jiaxing was similar to that in Taiwan Region. Several studies [35-37] have reported that biliary atresia is common in Asian countries, possibly attributed to racial and geographic factors. In addition, due to hypertrophic pyloric stenosis, Hirschsprung's disease and biliary atresia are usually detected more than seven days after birth, and data collected in this study cannot exclude the omission of the registration of birth defects. For example, some cases developed symptoms after the first seven days since birth, and attended other hospitals for treatment. However, compared with previous studies, the incidence in this study was within a reasonable range. Furthermore, the differences in incidence between previous reports from other countries and China may be attributable to racial, environmental, and genetic factors.

Of the 76 cases with congenital digestive tract defects in our study, $68.4 \%$ survived. Different digestive tract abnormalities may affect survival. The general consensus is that live-born cases with associated malformations may have higher rates of mortality [40,41]; in our study, $32.9 \%$ also congenital heart disease, and this may be a risk factor that reduces survival. Additionally, the incidence of digestive tract malformations in male infants was higher than in female infants (male: female=1.58:1), 
which was consistent with previous studies [42-44]. Compared with other congenital malformations, digestive tract defects are not easily detected immediately after birth, especially biliary atresia. In addition, the general population know little about congenital digestive tract defects, and it is necessary to educate patients about these diseases during the perinatal period and establish targeted prevention and awareness programs to prompt faster diagnosis and expedite treatment.

In the current study, although the association between preterm birth and congenital alimentary tract malformation was not assessed, more than a third of cases (39.2\%) were premature births. Other studies have reported similar results. For example, a study of esophageal atresia in 23 European regions found that one third of live-born infants with isolated esophageal atresia were born preterm (gestational age $<37$ weeks) [28], and this was also demonstrated in a study regarding isolated anal anomalies [43]. Some studies have also reported that low birth weight is associated with higher incidence of birth defects. Yoon et al. [44] found that the incidence of biliary atresia in infants weighing less than $2500 \mathrm{~g}$ was higher than in infants of normal weight, and considered that low birth weight was an independent risk factor for biliary atresia. Digestive tract malformation will undoubtedly affect the normal function of a newborn's digestive system, thereby hindering children's digestion and absorption of nutrients. In tandem with these findings, our study showed that more than a third (40.8\%) of the gastrointestinal malformation cases had lower birth weight than normal newborns. Most newborns with low birth weight are premature infants. Premature birth and low birth weight may be risk factors for the occurrence of digestive tract malformations. However, these findings require further investigation and research.

Our study had some limitations. Firstly, the database only covered a five-year period (2015-2019) of birth registration, meaning that our investigation utilized relatively short-term data. Secondly, newborn data in this study was not linked to maternal data, so it was not possible to consider or adjust for confounding factors such as perinatal health. In addition, congenital digestive tract defects are not easily diagnosed within seven days of birth, particularly hypertrophic pyloric stenosis, Hirschsprung's disease, and biliary atresia. Therefore, there may have been omissions in the registration of birth defects in our study and some inaccuracy in the incidence estimates for biliary atresia. However, A major strength of this study was based on the population of a region in mainland China. The estimated incidence of congenital digestive tract malformations in mainland China is based upon studies that have been published abroad. There is little to no local information on this subject specific to China, and we believe more accurate local data will assist clinicians, researchers, and healthcare planners in providing better diagnostic and prognostic outcomes for newborns and their families by establishing awareness programs and increasing and expediting diagnosis and treatment. Our findings point out that digestive tract defects are not always established immediately after birth, which naturally impacts upon the health of the newborn, and these findings support and are supported by the findings of numerous other studies published throughout the world, though none relate to China at the same level of specificity as ours. In addition, we found that roughly one third of our subjects with digestive tract defects also had concomitant congenital heart disease, suggesting a link between the two which may warrant further investigation. China is a vast territory with a large and fluid population base, so it is difficult to compile very large sample reports focusing on digestive tract malformations. Thus, so far the prevalence of congenital digestive tract 
defects among Chinese people is rarely reported. This study fills a gap in the incidence of digestive tract malformations.

\section{Conclusions}

The focus on digestive tract defects in the present report, using data from Jiaxing, China (2015-2019), is intended to provide more detailed information on the occurrence of these rare birth defects. This study estimated the incidence of digestive tract malformations, and the findings may provide a useful foundation for future epidemiologic studies of these congenital diseases. Moreover, our data will also be helpful in determining the resources needed for basic and public health research into digestive tract malformation in China.

\section{Abbreviations}

None

\section{Declarations}

\section{Acknowledgments}

The authors would like to thank Jiaxing Maternal and Child Health Care Hospital, and all participants who contributed to the study.

\section{Author's contributions}

Fangfang Song, Jie Chen and Wei Cai planned and implemented the study. Fangfang Song and Jie Chen collected the data. Fangfang Song did the statistical analysis. Fangfang Song and Jie Chen wrote the first draft of the manuscript. Wei Cai reviewed the manuscript. All Authors contributed to the discussing of the findings, revised the manuscript, and approved the final version.

\section{Funding}

This work was supported by the Shanghai Key Laboratory of Pediatric Gastroenterology and Nutrition (17DZ2272000), and the Foundation of Science and Technology Commission of Shanghai Municipality (19495810500).

\section{Availability of data and materials}

The datasets used and/or analysed during the current study are available from the corresponding author on reasonable request.

\section{Ethics approval and consent to participate}

This article does not contain any studies with animals and human performed by any of the authors. 


\section{Consent for publication}

Not applicable

\section{Competing interests}

The authors declare no conflict of interest.

\section{References}

1. Tuchmann-Duplessis, H. Environment and birth defects James F. Wilson. Academic Press, 1973, 305 pp. Birth Defects Research Part A Clinical \& Molecular Teratology. 2010; 13(2):192-193.

2. Vaos G, Misiakos EP. Congenital anomalies of the gastrointestinal tract diagnosed in adulthood-diagnosis and management. J Gastrointest Surg. 2010; 14:916-925. Https://doi:10.1007/s11605009-1124-z

3. Khoury MJ. Epidemiology of birth defects. Epidemiology Review. 1989; 11: 244. Https://doi:10.1093/oxfordjournals.epirev.a036042

4. Pedersen, Calzolari RN, Husby E, et al. Oesophageal atresia: prevalence, prenatal diagnosis and associated anomalies in 23 European regions. Archives of disease in childhood. 2012; 97:227-232. Https://doi:10.1136/archdischild-2011-300597

5. Best KE, Addor MC, Arriola L, et al. Hirschsprung's disease prevalence in Europe: A register based study. Birth Defects Research Part A Clinical \& Molecular Teratology. 2014; 100: 695-702. Https://doi:10.1002/bdra.23269

6. Zhan J, Feng J, Chen Y, et al. Incidence of biliary atresia associated congenital malformations: A retrospective multicenter study in China. Asian Journal of Surgery. 2016; 40: 429-433. Https://doi:10.1016/j.asjsur.2016.04.003

7. Wang WP, Xie W, Xia H, Rao WW, Zhu XD. Nutrition conditions of congenital malformation of the alimentary tract children in pediatric surgical intensive care unit. Clinical Misdiagnosis \& Mistherapy. 2018; 44: 19. Https://doi:10.1186/s13052-018-0445-5

8. Joensen F. Congenital malformations of urinary tract and gastrointestinal canal. Incidence of diagnosed cases at 2 years of age compared with prenatal registration. Ugeskr Laeger. 1996; 158 : 2246-2250.

9. Martínez-Frías ML, Castilla EE, Bermejo E, Prieto L, Orioli IM. Isolated small intestinal atresias in Latin America and Spain: epidemiological analysis. Am J Med Genet. 2000; 93: 355-359. Https://doi:10.1002/1096-8628(20000828)93:5<355::aid-ajmg3>3.0.co;2-q

10. Forrester MB, Merz RD. Population-based study of small intestinal atresia and stenosis, Hawaii, 1986-2000. Public Health. 2004; 118: 434-438. Https://doi:10.1016/j.puhe.2003.12.017

11. Hemming V, Rankin J. Small intestinal atresia in a defined population: occurrence, prenatal diagnosis and survival. Prenatal Diagnosis. 2010; 27:1205-1211. Https://doi:10.1002/pd.1886 
12. Khaw AV, Gaida-Hommernick B, Sehm B, et al. Multiple Atresia of the Small Intestine: A 20-Year Review. European Journal of Pediatric Surgery. 2008; 18:13-18. doi:10.1055/s-2007-965771

13. Wijers CHW, Blaauw ID, Marcelis CLM, et al. Research perspectives in the etiology of congenital anorectal malformations using data of the International Consortium on Anorectal Malformations: evidence for risk factors across different populations. Pediatric Surgery International. 2010; 26:10931099. Https://doi:10.1007/s00383-010-2688-0

14. Goossens WJH, Blaauw ID, Wijnen MH, et al. Urological anomalies in anorectal malformations in The Netherlands: effects of screening all patients on long-term outcome. Pediatric Surgery International. 2011; 27:1091-1097. Https://doi:10.1007/s00383-011-2959-4

15. Best KE, Tennant PWG, Addor MC, et al. Epidemiology of small intestinal atresia in Europe: a registerbased study. Archives of Disease in Childhood - Fetal and Neonatal Edition. 2012; 97: F353-F358. Https://doi:10.1136/fetalneonatal-2011-300631

16. Lupo PJ, Isenburg JL, Salemi JL, et al. Population-based birth defects data in the United States, 20102014: A focus on gastrointestinal defects. Birth Defects Research. 2017; 109:1504-1514. Https://doi:10.1002/bdr2.1145

17. Leong MM, Chen SC, Hsieh CS, et al. Epidemiological features of infantile hypertrophic pyloric stenosis in Taiwanese children: A Nation-Wide Analysis of Cases during 1997-2007. PLoS One. 2007; 6: e19404. Https://doi:10.1371/journal.pone.0019404

18. Walker $\mathrm{K}$, Badawi $\mathrm{N}$, Hamid $\mathrm{C} \mathrm{H}$, et al. A population-based study of the outcome after small bowel atresia/stenosis in New South Wales and the Australian Capital Territory, Australia, 1992-2003. Journal of Pediatric Surgery. 2008; 43:484-488. Https://doi:10.1016/j.jpedsurg.2007.10.028

19. Wei DC, Wang DC. The development on the etiology of hirschsprung's disease. The Journal of Practical Medicine. 2007; 23:299-300.

20. Shi J, Wu WJ, Cai W. Clinical treatment and short follow-up biliary atresia. Journal of Clinical Pediatric Surgery. 2010; 09: 175-177.

21. Wang J, Niu WY. Clinical analysis of 82 cases of congenital malrotation of intestine. Chinese Journal of Misdiagnostics. 2002; 2: 507-509.

22. Wang HY, Li BX, Zhou CG, Long Yi. Clinical experience in laparoscopic therapy for congenital intestinal atresia (a report of 30 cases). China Journal of Endoscopy. 2009; 15: 442-443.

23. Dalla Vecchia LK, Grosfeld JL, West KW, Rescorla FJ, Scherer LR, Engum SA. Intestinal Atresia and Stenosis: A 25-Year Experience With 277 Cases. Archives of Surgery. 1998; 133:490. Https://doi:10.1001/archsurg.133.5.490

24. Yu ZW, Yang Y, Li SL, et al. The experimental studies and clinical applications of laparoscopic duodenal single-layer sutured anastomosis in children. Journal of Clinical Pediatric Surgery. 2011; 10: $90-93$.

25. Jiaxing National Economic and Social Development report 2019, http://www.jiaxing.gov.cn/art/2020/3/18/art_1228921187_42312808.html; 2020 [accessed 18 March 2020]. 
26. Wang YL, Chen GJ, Cui YH, Fang F. Birth defects analysis of Jiaxing in 2006 to 2010. Clinical Focus. 2013; 28: 753-757.

27. Pedersen RN, Calzolari E, Husby S, Garne E, EUROCAT Working group. Oesophageal atresia: prevalence, prenatal diagnosis and associated anomalies in 23 European regions. Arch Dis Child. 2012; 97:227-232. Https://doi:10.1136/archdischild-2011-300597

28. Depaepe A, Dolk H, Lechat MF. The epidemiology of tracheo-oesophageal fistula and oesophageal atresia in Europe. EUROCAT Working Group. Arch Dis Child. 1993; 68(6):743-748. Https://doi:10.1136/adc.68.6.743

29. Forrester MB, Merz RD. Epidemiology of oesophageal atresia and tracheoo-esophageal fistula in Hawaii, 1986-2000. Public Health. 2005; 119: 483-8. Https://doi:10.1016/j.puhe.2004.07.008

30. Hedback, G. The epidemiology of infantile hypertrophic pyloric stenosis in Sweden 1987-96. Archives of Disease in Childhood. 2001; 85(5): 379-381. Https:// doi:10.1136/adc.85.5.379

31. Best KE, Glinianaia SV, Bythell M, Rankin J. Hirschsprung's disease in the North of England: prevalence, associated anomalies, and survival. Birth Defects Res A Clin Mol Teratol. 2012; 94:477480. Https://doi:10.1002/bdra.23016

32. International clearinghouse birth defect surveillance and research. Annual report 2008, with data for 2006.

33. Cuschieri A. Descriptive epidemiology of isolated anal anomalies: A survey of 4.6 million births in Europe. American Journal of Medical Genetics Part A. 2010; 103:207-215. Https://doi:10.1002/ajmg.1532.abs

34. Tiao MM, Tsai SS, Kuo HW, Chen CL, Yang CY. Epidemiological features of biliary atresia in Taiwan, a national study 1996-2003. J Gastroenterol Hepatol. 2008; 23:62-66.

Https://doi:10.1002/ajmg.1532.abs

35. Nio M, Ohi R, Miyano T, et al. Five- and 10-year survival rates after surgery for biliary atresia: a report from the Japanese Biliary Atresia Registry. J Pediatr Surg. 2003; 38: 997-1000. Https://doi:10.1016/s0022-3468(03)00178-7

36. Lee KJ, Kim JW, Moon JS, Ko JS. Epidemiology of Biliary Atresia in Korea. J Korean Med Sci. 2017; 32:656-660. Https://doi:10.3346/jkms.2017.32.4.656

37. Caton AR, Druschel CM, McNutt LA. The epidemiology of extrahepatic biliary atresia in New York State, 1983-98. Paediatr Perinat Epidemiol. 2004; 18: 97-105. Https://doi:10.1111/j.13653016.2003.00536.x

38. Shneider BL, Brown MB, Haber B, et al. A multicenter study of the outcome of biliary atresia in the United States, 1997 to 2000. J Pediatr. 2006; 148:467-474. Https://doi:10.1016/j.jpeds.2005.12.054

39. Xu G, Li BX, Zhou CG, Wang HY, Liu XX. Characteristics and prognostic influential factors of hospitalized infants with congenital digestive tract malformation. CJCHC. 2011; 19: 1142-1145.

40. Lee SE, Kim HY, Jung SE, Lee SC, Park KW, Kim WK. Situs anomalies and gastrointestinal abnormalities. J Pediatr Surg. 2006; 41:1237-1242. Https://doi:10.1016/j.jpedsurg.2006.03.045 
41. Goldberg EL. An epidemiological study of Hirschsprung's disease. Int J Epidemiol. 1984; 13: 479-485.

42. Cuschieri A, EUROCAT Working Group. Descriptive epidemiology of isolated anal anomalies: a survey of 4.6 million births in Europe. Am J Med Genet. 2001; 103:207-215.

Https://doi:10.1002/ajmg.1532.abs

43. Yoon PW, Bresee JS, Olney RS, James LM, Khoury MJ. Epidemiology of biliary atresia: a populationbased study. 1997; 99: 376-382. Https://doi:10.1542/peds.99.3.376

\section{Tables}

Table 1 The overall birth prevalence in Jiaxing China from 2015 to 2019

\begin{tabular}{|c|c|c|c|c|c|c|c|}
\hline & & $\begin{array}{l}2015 \\
\text { (Total } \\
\text { birth } \\
=8,409)\end{array}$ & $\begin{array}{l}2016 \\
\text { (Total } \\
\text { birth } \\
=11,359 \text { ) }\end{array}$ & $\begin{array}{l}2017 \\
\text { (Total } \\
\text { birth } \\
=11,365 \text { ) }\end{array}$ & $\begin{array}{l}2018 \\
\text { (Total } \\
\text { birth } \\
=8,693)\end{array}$ & $\begin{array}{l}2019 \text { (Total } \\
\text { birth }=8,548)\end{array}$ & $\begin{array}{l}\text { Total } \\
\text { (Total } \\
\text { birth } \\
=48,374 \text { ) }\end{array}$ \\
\hline & & n (\%) & n (\%) & n (\%) & $\mathrm{n}(\%)$ & $\mathrm{n}(\%)$ & n (\%) \\
\hline \multirow[t]{3}{*}{$\begin{array}{l}\text { Total } \\
\text { Birth }\end{array}$} & Male & $\begin{array}{l}4,410 \\
(52.44)\end{array}$ & $\begin{array}{l}5,908 \\
(52.01)\end{array}$ & $\begin{array}{l}5,902 \\
(51.93)\end{array}$ & $\begin{array}{l}4,462 \\
(51.33)\end{array}$ & $4,501(52.66)$ & $\begin{array}{l}25,183 \\
(52.06)\end{array}$ \\
\hline & Female & $\begin{array}{l}3,998 \\
(47.54)\end{array}$ & $\begin{array}{l}5,449 \\
(47.97)\end{array}$ & $\begin{array}{l}5,642 \\
(48.06)\end{array}$ & $\begin{array}{l}4,229 \\
(48.65)\end{array}$ & $\begin{array}{l}4,044 \\
(47.31)\end{array}$ & $\begin{array}{l}23,362 \\
(48.29)\end{array}$ \\
\hline & Unknown & $1(0.01)$ & $2(0.02)$ & $1(0.01)$ & $2(0.02)$ & $3(0.04)$ & $9(0.02)$ \\
\hline \multirow[t]{3}{*}{ Health } & Male & $\begin{array}{l}4,295 \\
(52.43)\end{array}$ & $\begin{array}{l}5,703 \\
(51.88)\end{array}$ & $\begin{array}{l}5,634 \\
(51.58)\end{array}$ & $\begin{array}{l}4,272 \\
(51.11)\end{array}$ & $\begin{array}{l}4,369 \\
(52.57)\end{array}$ & $\begin{array}{l}24,273 \\
(51.96)\end{array}$ \\
\hline & Female & $\begin{array}{l}3,896 \\
(47.56)\end{array}$ & $\begin{array}{l}5,289 \\
(48.12)\end{array}$ & $\begin{array}{l}5,232 \\
(48.15)\end{array}$ & $\begin{array}{l}4,086 \\
(48.89)\end{array}$ & $\begin{array}{l}3,942 \\
(47.43)\end{array}$ & $\begin{array}{l}22,445 \\
(46.40)\end{array}$ \\
\hline & Total & $\begin{array}{l}8,191 \\
(97.41)\end{array}$ & $\begin{array}{l}10,992 \\
(96.77)\end{array}$ & $\begin{array}{l}10,866 \\
(95.61)\end{array}$ & $\begin{array}{l}8,358 \\
(96.15)\end{array}$ & $\begin{array}{l}8,311 \\
(97.23)\end{array}$ & $\begin{array}{l}46,718 \\
(96.58)\end{array}$ \\
\hline \multirow[t]{4}{*}{ Defects } & Male & $\begin{array}{l}115 \\
(52.5)\end{array}$ & $\begin{array}{l}205 \\
(55.86)\end{array}$ & $\begin{array}{l}268 \\
(53.771)\end{array}$ & $\begin{array}{l}190 \\
(56.72)\end{array}$ & $132(55.70)$ & $\begin{array}{l}910 \\
(54.95)\end{array}$ \\
\hline & Female & $\begin{array}{l}102 \\
(46.79)\end{array}$ & $\begin{array}{l}160 \\
(43.60)\end{array}$ & $\begin{array}{l}230 \\
(46.09)\end{array}$ & $\begin{array}{l}143 \\
(42.69)\end{array}$ & $102(43.04)$ & $\begin{array}{l}737 \\
(44.50)\end{array}$ \\
\hline & Unknown & $1(0.46)$ & $2(0.54)$ & $1(0.20)$ & $2(0.06)$ & $3(1.26)$ & $9(0.54)$ \\
\hline & Total & $\begin{array}{l}218 \\
(2.59)\end{array}$ & $\begin{array}{l}367 \\
(3.23)\end{array}$ & $\begin{array}{l}499 \\
(4.39)\end{array}$ & $\begin{array}{l}335 \\
(3.85)\end{array}$ & 237 (2.77) & $\begin{array}{l}1,656 \\
(3.42)\end{array}$ \\
\hline
\end{tabular}


Table 2 Total prevalence of digestive tract defects in Jiaxing 2015-2019 


\begin{tabular}{|c|c|c|}
\hline Category & $\begin{array}{l}\text { Digestive tract } \\
\text { defects }\end{array}$ & 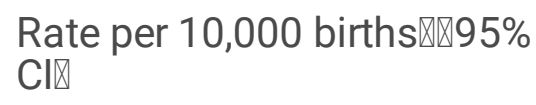 \\
\hline 2015 & $n=12$ & $n=8,409$ \\
\hline Esophageal atresia & 1 & $1.19(-)$ \\
\hline $\begin{array}{l}\text { Congenital defects of gastric } \\
\text { musculature }\end{array}$ & 0 & - \\
\hline Hypertrophic pyloric stenosis & 0 & - \\
\hline Duodenal and intestinal atresia & 3 & $3.57(-)$ \\
\hline Congenital malrotation of intestine & 0 & - \\
\hline Hirschsprung's disease & 1 & $1.19(-)$ \\
\hline Anal atresia/stricture & 7 & 4.75 (1.3 to 12.2$)$ \\
\hline Biliary atresia & 0 & - \\
\hline 2016 & $n=13$ & $n=11,359$ \\
\hline Esophageal atresia & 1 & $0.9(-)$ \\
\hline $\begin{array}{l}\text { Congenital defects of gastric } \\
\text { musculature }\end{array}$ & 2 & $1.8(-)$ \\
\hline Hypertrophic pyloric stenosis & 0 & - \\
\hline Duodenal and intestinal atresia & 4 & $3.5(-)$ \\
\hline Congenital malrotation of intestine & 4 & $3.5(-)$ \\
\hline Hirschsprung's disease & 1 & $0.9(-)$ \\
\hline Anal atresia/stricture & 1 & $0.9(-)$ \\
\hline Biliary atresia & 0 & - \\
\hline 2017 & $n=20$ & $n=11,365$ \\
\hline Esophageal atresia & 2 & $1.76(-)$ \\
\hline $\begin{array}{l}\text { Congenital defects of gastric } \\
\text { musculature }\end{array}$ & 0 & - \\
\hline Hypertrophic pyloric stenosis & 0 & - \\
\hline Duodenal and intestinal atresia & 5 & 4.40 (1.43 to 10.26$)$ \\
\hline Congenital malrotation of intestine & 1 & $0.9(-)$ \\
\hline Hirschsprung's disease & 1 & $0.9(-)$ \\
\hline Anal atresia/stricture & 9 & 7.92 (3.62 to 15.03$)$ \\
\hline
\end{tabular}




\begin{tabular}{|c|c|c|}
\hline Biliary atresia & 2 & $1.76(-)$ \\
\hline 2018 & $n=17$ & $n=8,693$ \\
\hline Esophageal atresia & 3 & $3.45(-)$ \\
\hline $\begin{array}{l}\text { Congenital defects of gastric } \\
\text { musculature }\end{array}$ & 2 & $2.30(-)$ \\
\hline Hypertrophic pyloric stenosis & 0 & - \\
\hline Duodenal and intestinal atresia & 5 & 5.75 (1.87 to 13.42$)$ \\
\hline Congenital malrotation of intestine & 1 & $1.1(-)$ \\
\hline Hirschsprung's disease & 2 & $2.30(-)$ \\
\hline Anal atresia/stricture & 3 & $3.45(-)$ \\
\hline Biliary atresia & 1 & $1.1(-)$ \\
\hline 2019 & $\mathrm{n}=16$ & $n=8,548$ \\
\hline Esophageal atresia & 1 & $1.16(-)$ \\
\hline $\begin{array}{l}\text { Congenital defects of gastric } \\
\text { musculature }\end{array}$ & 2 & $2.33(-)$ \\
\hline Hypertrophic pyloric stenosis & 2 & $2.33(-)$ \\
\hline Duodenal and intestinal atresia & 1 & $1.16(-)$ \\
\hline Congenital malrotation of intestine & 3 & $3.49(-)$ \\
\hline Hirschsprung's disease & 1 & $1.16(-)$ \\
\hline Anal atresia/stricture & 3 & $3.49(-)$ \\
\hline Biliary atresia & 1 & $1.16(-)$ \\
\hline Total & $n=76$ & $\mathrm{n}=48,374$ \\
\hline Esophageal atresia & 8 & $1.65(-)$ \\
\hline $\begin{array}{l}\text { Congenital defects of gastric } \\
\text { musculature }\end{array}$ & 6 & $1.24(-)$ \\
\hline Hypertrophic pyloric stenosis a & 2 & $2.33(-)$ \\
\hline Duodenal and intestinal atresia & 18 & $3.72(2.21-5.88)$ \\
\hline Congenital malrotation of intestine ${ }^{b}$ & 9 & $2.25(1.03-4.27)$ \\
\hline Hirschsprung's disease & 6 & $1.24(-)$ \\
\hline \multirow[t]{2}{*}{ Anal atresia/stricture } & 23 & $4.75(3.01-7.1)$ \\
\hline & 4 & $1.40(-)$ \\
\hline
\end{tabular}


a: Per 10,000 births of 2019(total=8,548; total defects=237)

b: Per 10,000 births from 2016 and 2019(total $=39,965$; total defects $=1,437$ )

c: Per 10,000 births from 2017 to 2019 (total $=28,606$; total defects $=1,071$ )

Table 3 Gender occurrence and outcome of digestive tract defects in Jiaxing 2015-2019 


\begin{tabular}{|c|c|c|c|c|c|c|}
\hline & & Cases & $\begin{array}{l}\text { Percentage } \\
\text { (\%) }\end{array}$ & Birth Type & Cases & $\begin{array}{l}\text { Percentage } \\
\text { (\%) }\end{array}$ \\
\hline \multirow[t]{3}{*}{ Esophageal atresia } & Male & 6 & 75.0 & $\begin{array}{l}0 \text { to } 6 \\
\text { days of } \\
\text { death }\end{array}$ & 2 & 25.0 \\
\hline & Female & 2 & 25.0 & Stillbirth & 1 & 12.5 \\
\hline & & & & Survive & 5 & 62.5 \\
\hline \multirow[t]{3}{*}{$\begin{array}{l}\text { Congenital defects of } \\
\text { gastric musculature }\end{array}$} & Male & 4 & 66.7 & $\begin{array}{l}0 \text { to } 6 \\
\text { days of } \\
\text { death }\end{array}$ & - & \\
\hline & Female & 2 & 33.3 & Stillbirth & - & \\
\hline & & & & Survive & 6 & 100 \\
\hline \multirow[t]{3}{*}{$\begin{array}{l}\text { Hypertrophic pyloric } \\
\text { stenosis }\end{array}$} & Male & 2 & 100 & $\begin{array}{l}0 \text { to } 6 \\
\text { days of } \\
\text { death }\end{array}$ & & \\
\hline & Female & & & Stillbirth & & \\
\hline & & & & Survive & 2 & 100 \\
\hline \multirow[t]{3}{*}{$\begin{array}{l}\text { Duodenal and intestinal } \\
\text { atresia }\end{array}$} & Male & 6 & 36.8 & $\begin{array}{l}0 \text { to } 6 \\
\text { days of } \\
\text { death }\end{array}$ & 1 & \\
\hline & Female & 11 & 57.8 & Stillbirth & 6 & \\
\hline & Unknown & 1 & 5.3 & Survive & 11 & \\
\hline \multirow[t]{3}{*}{$\begin{array}{l}\text { Congenital malrotation of } \\
\text { intestine }\end{array}$} & Male & 6 & 66.7 & $\begin{array}{l}0 \text { to } 6 \\
\text { days of } \\
\text { death }\end{array}$ & - & \\
\hline & Female & 3 & 33.3 & Stillbirth & - & \\
\hline & & & & Survive & 9 & 100 \\
\hline \multirow[t]{3}{*}{ Hirschsprung's disease } & Male & 4 & 66.7 & $\begin{array}{l}0 \text { to } 6 \\
\text { days of } \\
\text { death }\end{array}$ & - & - \\
\hline & Female & 2 & 33.3 & Stillbirth & - & - \\
\hline & & & & Survive & 6 & 100 \\
\hline \multirow[t]{2}{*}{ Anal atresia/stricture } & Male & 15 & 65.2 & $\begin{array}{l}0 \text { to } 6 \\
\text { days of } \\
\text { death }\end{array}$ & 4 & 17.4 \\
\hline & Female & 8 & 34.8 & Stillbirth & 1 & 4.3 \\
\hline
\end{tabular}




\begin{tabular}{|c|c|c|c|c|c|c|}
\hline & & & & Survive & 18 & 78.3 \\
\hline \multirow[t]{4}{*}{ Biliary atresia } & Male & 3 & 75.0 & $\begin{array}{l}0 \text { to } 6 \\
\text { days of } \\
\text { death }\end{array}$ & - & \\
\hline & Female & 1 & 25.0 & Stillbirth & - & \\
\hline & & & & Survive & 4 & 100 \\
\hline & Male & 46 & 60.5 & $\begin{array}{l}0 \text { to } 6 \\
\text { days of } \\
\text { death }\end{array}$ & 7 & 9.2 \\
\hline \multirow[t]{3}{*}{ Total } & Female & 29 & 38.2 & Stillbirth & 17 & 22.4 \\
\hline & Unknown & 1 & 1.3 & Survive & 52 & 68.4 \\
\hline & $\begin{array}{l}\text { Male: } \\
\text { Female }\end{array}$ & \multicolumn{2}{|c|}{ 1.58:1 } & & & \\
\hline
\end{tabular}

Table 4 Birth weight and gestational age of the digestive tract defects in Jiaxing 2015-2019

\begin{tabular}{|lcl|}
\hline & $\begin{array}{c}\text { Cases } \\
\mathrm{n}=76\end{array}$ & $\begin{array}{l}\text { Percentage } \\
\%\end{array}$ \\
\hline \multicolumn{1}{|l}{ Birth weight $(2589.01 \pm 877.4)$} & $(\mathrm{g}) \ddagger$ \\
\hline$<1500$ & 11 & 14.5 \\
\hline $1500-2499$ & 20 & 26.3 \\
\hline$\geq 2500$ & 45 & 59.2 \\
\hline Gestational age $(36.0 \pm 4.0)$ & $($ weeks $) \neq$ \\
\hline$<37$ & 28 & 36.8 \\
\hline$\geq 37$ & 48 & 63.2 \\
\hline Congenital heart disease & & \\
\hline Yes & 25 & 32.9 \\
\hline No & 51 & 67.1 \\
\hline
\end{tabular}

$¥:$ Mean $\pm S D$

Table 5. Incidence and category of digestive tract defects in different regions 


\begin{tabular}{|c|c|c|c|}
\hline Category & Area & $\begin{array}{l}\text { Survey } \\
\text { Year }\end{array}$ & $\begin{array}{l}\text { Incidence } \\
\text { (per 10,000 births) }\end{array}$ \\
\hline \multirow[t]{4}{*}{$\begin{array}{l}\text { Esophageal } \\
\text { atresia }\end{array}$} & $\begin{array}{l}\text { Jiaxing, } \\
\text { China }\end{array}$ & $\begin{array}{l}2015- \\
2019\end{array}$ & 1.65 \\
\hline & Europe & $\begin{array}{l}1987- \\
2006\end{array}$ & $2.43(2.23-2.57)$ (Pedersen, et al., 2012) \\
\hline & Europe & $\begin{array}{l}1980- \\
1988\end{array}$ & 2.86 (Depaepe, et al., 1993) \\
\hline & Hawaii & $\begin{array}{l}1989- \\
2000\end{array}$ & 2.2 (Forrester \& Merz, 2005) \\
\hline \multirow[t]{3}{*}{$\begin{array}{l}\text { Hypertrophic } \\
\text { pyloric stenosis }\end{array}$} & $\begin{array}{l}\text { Jiaxing, } \\
\text { China }\end{array}$ & 2019 & 2.14 \\
\hline & $\begin{array}{l}\text { Taiwan } \\
\text { Region }\end{array}$ & $\begin{array}{l}1997- \\
2007\end{array}$ & 3.9 (3.0-4.7) (Leong, et al., 2007) \\
\hline & Sweden & $\begin{array}{l}1987- \\
1996\end{array}$ & 8.5 (Hedback, 2001) \\
\hline \multirow[t]{2}{*}{$\begin{array}{l}\text { Duodenal and } \\
\text { intestinal atresia }\end{array}$} & $\begin{array}{l}\text { Jiaxing, } \\
\text { China }\end{array}$ & $\begin{array}{l}2015- \\
2019\end{array}$ & 3.72 \\
\hline & England & $\begin{array}{l}1991- \\
2001\end{array}$ & $0.7-1.8$ (Best, et al., 2012) \\
\hline \multirow[t]{3}{*}{$\begin{array}{l}\text { Hirschsprung's } \\
\text { disease }\end{array}$} & $\begin{array}{l}\text { Jiaxing, } \\
\text { China }\end{array}$ & $\begin{array}{l}2015- \\
2019\end{array}$ & 2.14 \\
\hline & Europe & 2012 & 1.09 (1.03-1.15) (Best, et al., 2014) \\
\hline & England & $\begin{array}{l}1990- \\
2008\end{array}$ & $\begin{array}{l}1.63(1.33-1.98) \text { (International clearinghouse birth } \\
\text { defect surveillance and research. Annual report, 2008) }\end{array}$ \\
\hline \multirow[t]{3}{*}{$\begin{array}{l}\text { Anal } \\
\text { atresia/stricture }\end{array}$} & $\begin{array}{l}\text { Jiaxing, } \\
\text { China }\end{array}$ & $\begin{array}{l}2015- \\
2019\end{array}$ & 4.75 \\
\hline & Europe & $\begin{array}{l}1980- \\
1994\end{array}$ & 4.05 (Cuschieri, 2010) \\
\hline & Worldwide & 2006 & 2.0-6.67 (Tiao, et al., 2008) \\
\hline \multirow[t]{4}{*}{ Biliary atresia } & $\begin{array}{l}\text { Jiaxing, } \\
\text { China }\end{array}$ & $\begin{array}{l}2017- \\
2019\end{array}$ & 1.4 \\
\hline & $\begin{array}{l}\text { Taiwan } \\
\text { Region }\end{array}$ & $\begin{array}{l}1996- \\
2003\end{array}$ & $1.46(0.89-1.90)$ (Tiao, et al., 2008) \\
\hline & Japan & $\begin{array}{l}1989- \\
1999\end{array}$ & 0.96 (Nio, et al., 2003) \\
\hline & Korea & $\begin{array}{l}2011- \\
2015\end{array}$ & 1.06 (0.93-1.19) (Lee, et al., 2017) \\
\hline
\end{tabular}


$\begin{array}{lll}\text { New York } & 1983- \\ 1998\end{array} \quad 0.85(0.76-0.93)$ (Caton, et al., 2004)

USA $\quad$ 1997- $\quad 0.65-0.85$ (Shneider, et al., 2006) 2000 